Campbell University School of Law

Scholarly Repository @ Campbell University School of Law

\title{
The Bologna Process and German Legal Education: Developing Professional Competence through Clinical Experiences
}

\author{
William A. Woodruff \\ Campbell University School of Law, woodruffw@campbell.edu
}

Andreas Bucker

Follow this and additional works at: https://scholarship.law.campbell.edu/fac_sw

\section{Recommended Citation}

William A. Woodruff \& Andreas Bucker, The Bologna Process and German Legal Education: Developing Professional Competence through Clinical Experiences, 9 German L.J. 575 (2008).

Available at: https://scholarship.law.campbell.edu/fac_sw/36 


\title{
The Bologna Process and German Legal Education: Developing Professional Competence through Clinical Experiences
}

\author{
By Andreas Bücker* and William A. Woodruff*
}

\section{A. Introduction}

The Bologna Declaration of 19 June 1999, committed 29 European nations, including Germany, to develop a system of higher education

based on two main cycles, undergraduate and graduate. Access to the second cycle shall require successful completion of first cycle studies, lasting a minimum of three years. The degree awarded after the first cycle shall also be relevant to the European labour market as an appropriate level of qualification. The second cycle should lead to the master and/or doctorate degree as in many European countries. ${ }^{1}$

\footnotetext{
"Professor of Law, Hochschule Wismar, Wismar, Germany. E-mail: andreas.buecker@hs-wismar.de.

** Professor of Law, Norman Adrian Wiggins School of Law, Campbell University, Buies Creek, North Carolina, USA. E-mail: woodruff@law.campbell.edu. The author extends a special thanks to Clint Byrd (2009 Campbell University School of Law JD candidate) for his research and German language assistance on this article.

1 The Bologna Declaration of 19 June 1999, http://www.bologna-bergen2005.no/Docs/00Main_doc/990719BOLOGNA_DECLARATION.PDF (last accessed March 8, 2008). The Bologna Process involves far more than just the two-cycle education system. The purpose of the Bologna Process is to create the European higher education area by making academic degree standards and quality assurance standards more comparable and compatible throughout Europe. The Bologna Declaration encourages, among other things, the European co-operation in quality assurance of higher education with a view to developing comparable criteria and methodologies. Other important goals agreed in Bologna are easily comparable degrees, a system based on two main degree cycles (subsequently a third cycle has been included), a common European system of credits and mobility of students and teachers. See generally The Bologna Process at http:/ / www.bologna-bergen2005.no (last accessed March 6, 2008).
} 
While the goals of the Bologna Declaration are laudable, they were not received with enthusiasm by German law faculties. ${ }^{2}$ The current German system of legal education requires four years of study at the university level in order to sit for the Erste Staatsexamen (first state exam). Passing this test allows the aspiring lawyer to enter the two-year Referendariat (practical legal training) and obtain practical experience working in a private law office, a governmental agency, or with a judicial officer. Completion of this phase of training allows one to take the Zweite Staatsexamen (second state exam). Successful completion of the Zweite Staatsexamen qualifies one under the German Judiciary Act to seek appointment as a judge or to enter the practice of law as a licensed lawyer. Law faculties worried that reducing the university course work from fours years to three, as the Bologna Declaration envisions, would leave students ill prepared for the challenging Erste Staatsexamen. Furthermore, a bachelor's degree in law but an inability to pass the Erste Staatsexamen would hinder, not enhance, the student's qualification for the labor market. There is already a well-developed educational system for training legal support personnel administered by the Fachhochschulen (schools of applied science). Sending three-year bachelor degreed law students into the job market would either undercut the Fachhochschulen efforts or leave the bachelor degreed graduates with no meaningful access to employment in the legal field.

For these reasons, the Bologna process, now in its eighth year, has sparked considerable debate in the German legal academy. ${ }^{3}$ Conceptually, standardizing the educational system among European nations seems like an idea whose time has come. As the borders between European nations become less apparent, as monetary systems become uniform, as commerce and industry increasingly become multi-national, and as Europe is regarded as a single entity on the international stage it makes sense to develop a uniform educational system. But becoming a lawyer is not just about the courses offered at the university or the type of degree awarded. One does not automatically become a lawyer upon earning a university degree. The German Federal government, as well as the various Lander (states within the Federal Republic of Germany), control the entry into the profession. While the education system and the law faculties of Germany's universities play a vital role in the process of turning a student into a lawyer, in the final analysis it is a combination of the university course work and the standards imposed by the profession through the various governmental entities that has the final say. Complying with the Bologna process as it applies to legal education requires

\footnotetext{
2 Peter M. Huber, Der "Bologna - Prozess" und seine Bedeutung für die deutsche Juristenausbildung [The Bologna Process and its Impact on German Legal Training], 1 EUR. JN. LEGAL EDUC. 35 (2004).

${ }^{3}$ Johannes Riedel, The Bologna Process and Its Relevance for Legal Education in Germany, 2 EUR. JN. LEGAL EDUC. 59 (2005).
} 
consideration of whether the traditional law programs leading to the Erste Staatsexamen should be adjusted to the two-cycle bachelor's/masters structure and whether the two years of practical training prior to the Zweite Staatsexamen should be altered. ${ }^{4}$

When discussing the legal education of young lawyers in Germany we must remember the plethora of recently established bachelor's and master's programs in business law. ${ }^{2}$ These programs are mostly interdisciplinary including law (approximately 60-70\% of the workload), economics (approximately 20-30\% of the workload) and soft skills (approximately $10 \%$ of the workload). They do not lead to the Erste Staatsexamen and they do not qualify the student for Referendariat. These programs began as "Diplom" programs and practical training took place during the so called practical semester. The adaptation of the former "Diplom" programs to the two cycle bachelor's / master's system has fueled the debate about how to conduct practical training in these programs.

Both traditional legal education programs leading to the Erste Staatsexamen and the new bachelor's / master's programs must deal with the issue of how to structure the formal training of law students in the competencies and skills required of new lawyers. Before turning to the formal structure of legal education, however, we must first ask: which competencies and skills are required for a successful career as a lawyer? One aim of the Bologna process is curricular reform: bachelor's and master's programs must provide students not just with technical knowledge of the

\footnotetext{
4 Heino Schöbel, Die Bologna-Erklärung und die Juristenausbildung - Ein Bericht, 138 BAYERISCHE VerwaltungsblätTER (BAYVBL) 97 - 108 (2007); Jens Jeep, Der Bologna-Prozess und die deutsche Juristenausbildung: Warum die Sorge vor Bachelor und Master unberechtigt ist, 60 DIE ÖFFENTLICHE VERWALTUNG (DÖV) 411 (2007); Frank Engelmann, Bologna statt Sparte oder: Die Zukunft der Juristenausbildung, 61 NEUE JUSTIZ (NJ) 60-62 (2007); Hermann Stephan, Bologna-Prozess und Juristenausbildung, 60 DÖV 420 - 423 (2007); Ulrich Goll, Bachelor und Master statt Staatsexamen und Referendariat, 62 BETRIEBS BERATER (BB) Die erste Seite, Heft 20 (2007); Lutz Mackebrandt und Bernhard Dombeck, Entwurf des Rechtsdienstleistungsgesetzes: das Ei des Kolumbus?, 62 BB Die erste Seite, Heft 14 (2007); Laurel S. Terry, Lioing with the Bologna Process: Recommendations to the German Legal Education Community from a U.S. Perspectioe, 7 GERMAN LAW JOURNAL 863 (2006), Jens Jeep, Bologna: Stärken bewaliren, Chancen nutzen, 61 JURISTEN ZEITUNG 459 (2006); Matthias Kilian, Die Europäisierung des Hochschulraums, 61 JURISTEN ZEITUNG 209 (2006); Hein Kötz, Bologna als Chance, 61 JURISTEN ZEITUNG 397 (2006); Barbara Dauner-Lieb, Der Bologna-Prozess - endgültig kein Thema fïr die Juristenausbildung? 56 ANWALTSBLATT 5 (2006); Günter Krings, Der Bologna-Prozess und seine Auswirkungen auf die Juristenausbildung in Deutscluland, 42 RECHT UND POLITIK 18 (2006).

5 See http://www.studienwahl.de/index.aspx?bybegriff=Wirtschaftsrecht (last accessed March 9, 2008) for detailed information and a list of over 100 programs.
} 
law but also with competences and skills required for a successful legal career and active participation in economy and society. ${ }^{6}$

Because the ultimate goal of legal education is to prepare law students for careers as legal practitioners, focusing too narrowly on the structural modifications envisioned by the Bologna process runs the risk of sacrificing the important on the altar of the immediate. Those responsible for training new lawyers for German society must keep the ultimate goal in mind as they strive to comply with the Bologna initiatives. In this regard, it is useful to examine how lawyers are trained in the United States and ask whether the US experience can be of any benefit to the German legal academy as they consider the task of training competent professionals in the new paradigm imposed by the Bologna process. In particular, we consider whether the American concept of clinical legal education can help German curriculum reformers comply with the Bologna process while achieving the ultimate goal of preparing new lawyers for a professional career in law.

We begin this analysis in Section B by reviewing the history of legal education in the United States, tracing the development of American clinical legal education, identifying the essential skills and values American legal education seeks to impart, and briefly considering the future of clinical legal education in the United States. Section $C$ applies the American clinical paradigm to some of the issues facing German legal education in light of the Bologna reforms and offers suggestions on how German law faculties can draw upon the American experience to develop curricula that trains legal professionals and also satisfies the Bologna mandates. In Section D we conclude that integrating clinical experiences into the German law curriculum can improve the training of German law students and help satisfy the goals of the Bologna Process. We recommend German law faculties consider the American model of clinical education as they reform legal education to meet the demands of the Bologna Process.

\section{B. Overview of American Legal Education}

\section{Historic Development of Clinical Education}

At its most basic level, clinical legal education is a method of training law students by putting them in situations where they must apply the legal theory, principles, and doctrines they have studied in the classroom setting. While often thought of as a way to develop lawyering skills, such as interviewing, counselling, oral advocacy,

\footnotetext{
6 European Commission, From Bergen to London - The contribution of the European Commission to the Bologna Process, Brussels, 7 May 2007, http://ec.europa.eu/education/policies/educ/bologna/ report06.pdf (last accessed March 9, 2008) .
} 
negotiating, and writing persuasively, clinical legal education actually does much more. Certainly, the clinical setting facilitates the development of lawyering skills, but it also requires the student to not only consider how legal theory or doctrine actually applies in a concrete situation, but to actually plan how to apply an abstract legal rule to an actual situation, and to execute the plan. Thus, clinical legal education, much like clinical medical education, puts the classroom theory into actual practice.

Clinical legal education is not new. Indeed, it may be said that clinical legal education actually existed prior to the rise of the study of law as an academic discipline. Aspiring lawyers in Colonial America qualified to practice law by either participation in one of England's Inns of Court, hiring on as an apprentice to a practicing lawyer, or through the study of the classical legal treatises of the time. ${ }^{7}$ Both the Inns of Court and the apprentice method, the two most popular routes to law practice, involved working under the supervision of lawyers in the day-to-day practice of law. While the scope of the experiences encountered, the degree of supervision, and the meaningfulness of the training experience varied tremendously, the method of training was, essentially, work with a practicing lawyer and learn by assisting in the case at hand.

The advent of proprietary law schools and the creation of law professorships at existing colleges shortly after the American Revolution opened up new avenues for legal training. Perhaps the earliest example is the establishment of the Professorship of Law and Police by Thomas Jefferson at the College of William and Mary in 1779.8 George Wythe, the first appointee to this position, lectured undergraduates, aspiring lawyers, as well as interested citizens on the interrelationship between law and politics, a topic of critical importance to the new nation. ${ }^{9}$ Interestingly, however, Wythe did not limit his teaching to the formal lecture format. He incorporated moot court and mock legislative sessions into his curriculum and may have created the first simulated clinical experience in legal education. ${ }^{10}$ Wythe's successors and holders of similar professorships at other colleges moved toward a broad, theoretical approach to law teaching. The idea was

\footnotetext{
7 Charles R. McManis, The History of First Century American Legal Education: A Revisionist Perspective, 59 WASHINGTON UNIVERSITY LAW QUARTERLY 597, 601-602 (1982).

8Id. at 609.

${ }^{9} \mathrm{Id}$.

$10 \mathrm{Id}$. As discussed infra, Section B. III, clinical programs can be categorized into three broad groups, (1) simulated clinics, (2) live-client clinics and (3) externships. Each provides training in the practical application of legal doctrine and theory to real-world problems.
} 
to give lawyers, as well as citizens generally, a solid theoretical underpinning of the workings of government and the roles and responsibilities of its legal institutions. ${ }^{11}$

This broad "liberal arts" view of legal education persisted into the early $19^{\text {th }}$ century. Instead of preparing men for the practice of law, legal education was part of the fundamental base of knowledge thought necessary for leadership and good citizenship in the early days of the county. The shift from the study of law as part of a sound undergraduate educational experience to a more narrow professional education can be traced to the reformation of Harvard's law school by Justice Joseph Story in 1829.12 Story's reforms dispensed with the study of government, political science, and philosophy as necessary underpinnings to the study of law. Rather, he directed his efforts to bringing order and organization to the growing body of judge-made law produced by America's common law courts. ${ }^{13}$ The study of law was an academic exercise focused on making sense of judicial decisions handed down by American judges. As a jurist himself, Story no doubt focused on that aspect of law with which he was most familiar: judge-made law. Indeed, Story's academic interest in law pre-dated both his appointment to the Supreme Court and to Harvard. As a practitioner in Massachusetts Story began writing digests of American court decisions as supplements to the standard English treatises, such as Blackstone and Coke, which were the primary reference sources for American lawyers at that time. As one commentator has noted: "the purpose of Story's law school was not so much the development of American lawyers as the development of American law."14 Thus, there was little room in Harvard's classroom for teaching the practical skills of lawyering or otherwise preparing law students to become practicing lawyers.

Justice Story's influence on the development of American legal education as an academic exercise, as opposed to imparting the skills necessary to actually practice law, was bolstered by Christopher Columbus Langdell's introduction of the case method of study at Harvard in 1870.15 Langdell believed that by studying the

\footnotetext{
${ }^{11} I d$, at $611-615$.

12 Id. at 628; see also ALLAN FARNSWORTH, AN INTRODUCTION TO THE LEGAL SYSTEM OF THE UNITED STATES 17 ( $3 \mathrm{~d}$ ed. 1996). Joseph Story was appointed Associate Justice of the Supreme Court of the United States by President James Madison in 1811. During this period in American history Supreme Court justices also presided at trials as Circuit Judges. His appointment to Harvard did not require him to resign his seat on the Supreme Court. He remained on the Court until his death in 1845.

13 McManis, supra note 7 , at 630 .

${ }^{14} I d$.

${ }^{15} I d$ at 633.
} 
opinions of appellate courts, one could discover the substantive principles underlying legal rules and doctrines and thus further refine Story's goal of bringing order and organization to the ever-growing corpus of American law. ${ }^{16}$ The combination of Story's narrowing the subject matter of legal studies and Langdell's methodology, applied principally through the Socratic dialogue method of instruction, shifted legal education from a search for substantive legal principles to imparting a process of reasoning and the development of analytical thinking skills. ${ }^{17}$ As a result, "thinking like a lawyer" became the focus of formal legal education in American law schools.

The Story-Langdell influence was reinforced by several factors during the late $19^{\text {th }}$ and early $20^{\text {th }}$ centuries. ${ }^{18}$ First, was the establishment of new university affiliated law schools around the country. In 1870 when Langdell introduced the case method at Harvard, there were 31 law schools in the United States with some 1600 students enrolled. Twenty four years later the number of schools had reached 72 and the enrolment was $7,600.19$ Sixty five of those schools were associated with established universities. ${ }^{20}$ By the turn of the century the apprenticeship method of law training had been supplanted by a formal course of academic study at an established law school. Law was firmly established as a legitimate field of academic inquiry.

The second factor shaping the development of legal education was the establishment of the American Bar Association (ABA) and its interest in legal education. The inaugural meeting of the American Bar Association was held in Saratoga, New York, in August 1878. ${ }^{21}$ From its inception, the ABA expressed an interest in legal education and the standards for admission to the bar. Indeed, one of the standing committees created by the organization's first constitution was the Committee of Legal Education and Admission to the Bar. ${ }^{22}$ While early efforts to assert the ABA's influence on the legal academy met with little success, due in no

\footnotetext{
${ }^{16} I d$.

17 Id. at 634 .

18 While Story and Langdell are credited with the development of the professional model of legal education based upon the case method some have suggested that much of the real credit goes to those who actually implemented and refined their ideas. Id., 631-637.

${ }^{19}$ Albert J. Haro, LEgal EduCAtion in the United States 51, 82 (1953).

$20 \mathrm{Td}$. at 82 .

21 Id. at 73 .

22 Id.
} 
small part to the fact that most of the member lawyers were products of the old apprentice system and not graduates of law school, in 1892 things changed. At the annual meeting the Association adopted resolutions urging the states to establish and support law schools and recommending at least two years of law study be required for bar admission..$^{23}$ The following year the Association created the Section on Legal Education, a forum to study, consider, debate, and recommend advancements in legal education. Its resolutions, reports, and recommendations were passed to the Committee of Legal Education and Admission to the Bar for presentation to the entire Association. One commentator has described the creation of the Section on Legal Education as "a life line" for legal education in America. ${ }^{24}$ Its early members and officers were leaders of the profession and they uniformly supported the growing academic discipline of law study at the graduate level. ${ }^{25}$

The interest of the ABA in legal education spawned the third major influence on the development of the American system of legal education, the creation of the American Association of Law Schools (AALS) as the learned society for law teachers. At their 1899 meeting the ABA's Section on Legal Education formed a committee to explore ways to increase the communications and contacts between the Section and the law schools. All law schools in the country were invited to send representatives to the next annual meeting of the Section. Fifty four professors representing 35 law schools attended the 1900 meeting of the Section. ${ }^{26}$ AALS was created and took for its mission "the improvement of legal education in America." 27 Composed of like-minded law schools, the first order of business was adoption of articles of association that restricted membership to law schools that:

(1) required of candidates for its degree the completion of a high-school course, or its equivalent; (2) maintained a course of study leading to its degree that covered at least two years of thirty weeks per year, provided that after 1905 a member school had to require a three years' course; (3) owned, or had

\footnotetext{
23 James P. White, The American Bar Association Law School Approval Process: A Century Plus of Public Seroice, 30 WAKE FOREST LAW REVIEW 283 (1995).

${ }^{24}$ HARO, supra note 19 , at 81 .

${ }^{25}$ The influence of the ABA on legal education has not waned over the ensuring decades. The Association now serves as the primary accrediting agency for American law schools and sets comprehensive standards for evaluating the quality of a school's educational program.

${ }^{26}$ HARO, supra note 19 , at 89.

27 Id.
} 
convenient access to during all regular library hours, a library that contained the reports of the state in which the school was located and the reports of the Supreme Court of the United States. ${ }^{28}$

With the creation of AALS as the learned society of law teachers there were now two influential groups directing the future of American legal education, the practicing bar as represented by the $\mathrm{ABA}$, and a consortium of like-minded law professors. As early as 1903 the ABA began a program of inspections to insure member schools were in compliance with the standards adopted at its formation. The AALS continued to meet at the same time as the ABA until 1914 when the ABA meeting conflicted with the normal school term and made it impossible for the AALS representatives to attend. As a result, the AALS became a completely independent association. This parting of the ways hindered the goal of increased communication between the bar and the academy. On the other hand, it furthered the development of the study of law as an academic discipline. The separation between the bar and the academy naturally widened over the ensuing decades as the professorial class became a distinct branch of the legal profession. As will be seen, the need for and development of clinical legal education served as a bridge between the two professions.

The fourth factor reinforcing the study of law as an academic discipline, as opposed to a trade learned as a practitioner's apprentice, was the inclusion of formal legal education as a prerequisite for admission to the bar. The entrance to the legal profession in America is controlled by the various states. During the early days of the nation admission to the bar was through the precursors of the modern bar associations. Practitioners formed voluntary societies and established rules to govern who could join the society. The rules often specified, among other things, the length of time an applicant had to spend reading law in the chambers of a member of the society. ${ }^{29}$

But even these modest qualifications were discarded in the early decades of the $1^{\text {th }}$ century as the nation struggled to implement the goals of the American Revolution. Fearing that bar societies developing rules to control admission to practice denied otherwise good citizens their natural right to pursue their chosen livelihood, state legislatures began to pass laws and include provisions in state constitutions preserving the right of every man of good character to practice law. The fear of lawyers becoming the new American aristocracy prompted states like New

\footnotetext{
${ }^{28}$ Id. (quoting 23 REPORTS OF AMERICAN BAR ASSOCIATION (REP. AM. BAR ASS'N) 447-458 (1900)).

${ }^{29}$ ROSCOE POUND, THE LAWYER FROM ANTIQUITY TO MODERN TIMES 187-91 (1953).
} 
Hampshire to open the practice of law to "every citizen over twenty-one years of age." 30 Maine admitted "every citizen" to the practice of law. ${ }^{31}$ "Every resident" of Wisconsin was eligible to represent others before the courts of that state. ${ }^{32}$

This era of radical Jeffersonian democracy and the de-professionalization of the bar persisted until after the Civil War. As the study of law became a recognized academic discipline, as lawyers formed voluntary associations to restore a sense of professionalism to the practice of law, and as law teachers began to be recognized as a distinct part of the legal profession, pressure began to mount on the states to regulate the profession and establish qualifications for admission to practice. Some of the early resolutions of the ABA dealt with standards for admission to practice and recommended the various state supreme courts control admission to practice. Later resolutions specifically urged the states to include graduation from law school as a prerequisite to admission. ${ }^{33}$

These rather modest efforts to establish formal legal study as a prerequisite to the admission to the practice of law were not without opposition. Some feared placing such emphasis on a law school degree

would be to place the control of legal education through the country in the hands of the deans of a few large day law schools who have the fate of law teachers in their hands. It would close the profession of the law to all save the leisure class of youth with means sufficient to obtain college and law school training, and would bar hundreds of naturally well-endowed, zealous and industrious youths from attaining an honourable ambition. It would result, in large communities, in the establishment of legal factories with a few lawyers at the head and all other mere clerks, cut off from the hope of entering the profession. Finally, it would discourage legal education throughout the country, decrease legal knowledge everywhere, and deprive masses of people in our large cities, many of them of

\footnotetext{
${ }^{30}$ Id. at 231.

$31 \mathrm{Id}$.

${ }^{32} \mathrm{Id}$.

33 HARO, supra note 19, at 104-05.
} 
foreign extraction, from access to our courts and legal aid for want of lawyers familiar with their language and distinctive customs. ${ }^{34}$

Despite the opposition, the early decades of the $20^{\text {th }}$ century saw states amending their laws to require formal legal education as a prerequisite to practice law. By the middle of the century, the formal study of law at the university level was firmly established as the gateway to the profession.

As legal education became more academic it also became less practice oriented. Through the case method of instruction law students learned to think like a lawyer, but they did not learn to "do" like a lawyer. Legal theory and doctrine, not practical application to real problems of real clients, was the coin of the realm in the legal academy. This migration from apprenticeship to academic inquiry in training lawyers was not, however, without its critics. Some saw the developing gap between legal education and legal practice as a threat to the profession and a detriment to clients. In 1917, William V. Rowe, a member of the New York bar, worried that the growing complexity of the law, coupled with a burgeoning population of new immigrants from Europe without a common foundation in America's legal system, created a professional crisis that could only be corrected by training American lawyers in practicing law and not just thinking about law. Drawing upon the common practice of medical clinical training, he proposed a clinical component to legal education in New York:

Like a surgical or medical clinic, but in much greater degree, this clinical course will mean earnest, redblooded talks and 'demonstrations,' in a classroom, with close analytical arguments between lawyer and student, concerning the concrete living cases actually being handled by the students from day to day. . . . [T] he purpose of the clinic, not merely to educate in practice and to develop, in general, the true professional spirit, but, in the interest of the commonwealth and of good citizenship, to lay the foundations in the individual student for sound personal character and business honor, to make clear, in the concrete, the lawyer's duty to society and to his fellow-men, and, in so doing, to combat the idea . . . that the law is simply one means, like any trade, of

\footnotetext{
${ }^{34}$ Id. at 107-08 (quoting John Marshall Law School Dean Edward T. Lee, 46 AM. BAR ASs'N, 685 (1921)).
} 
making a living, and is freely open to the world without serious restrictions as to qualifications, and with no special resulting social obligations. Among other things, the student must understand the lawyer's duty, like the doctor's, to give his best service to the poor - to a non-paying clientage. In short, it must be made possible for the student to absorb and acquire from this clinical experience correct standards as to business, honor, civic duty, charity and social service. ${ }^{35}$

In 1933, another critic of the dominant case-method of instruction in American law schools argued that law students studying under Langdell's case method were "like future horticulturists confining their studies to cut flowers . . or prospective dog breeders who never see anything but stuffed dogs." ${ }^{36}$ In 1944, Karl Llewellyn of Columbia Law School reported to the AALS Curriculum Committee, the "current case-instruction is somehow failing to do the job of producing reliable professional competence. .." in law school graduates. ${ }^{37}$ Despite these criticisms, the case method remained the dominant method of legal instruction. Clinical education was far from prevalent in America's law schools. Duke University opened an in-house legal aid clinic in 1931. Some sixteen years later, the University of Tennessee opened an in-house clinic. By 1950 only 25 of the 115 law schools approved by the ABA offered clinical opportunities for their students.

While the first half of the $20^{\text {th }}$ Century saw very little curricular reform toward clinical training, the second half of the century was marked by just the opposite. The post-war economic expansion brought an increased awareness of the plight of the poor and disadvantaged in American society. Government programs like the "War on Poverty" and taxpayer funded legal services offices attempted to bring legal aid to those who could not afford private legal counsel. ${ }^{38}$ The Supreme Court's decision in Gideon 0 . Wainright ${ }^{39}$ required the states to provide legal counsel

\footnotetext{
${ }^{35}$ William V. Rowe, Legal Clinics and Better Trained Lawyers - A Necessity, ILLINOIS LAW RevIEW 591, 607 (1917).

${ }^{36}$ Jerome Frank, Why Not a Clinical Lawyer-School, 81 PENNSYLVANIA LAW REVIEW 907, 912 (1933).

${ }^{37}$ Robert Stevens, LAW SCHOOL: LEGAL EDUCATION IN AMERICA FROM THE 1850S TO THE 1980S, 214 (2001).

${ }^{38}$ George S. Grossman, Clinical Legal Education: History and Diagnosis, 26 JOURNAL OF LEGAL EDUCATION 162,173 (1974). Most of these "legal aid clinics" were actually externships where law students worked at an existing legal aid society under the supervision of a legal aid attorney. Quintin Johnstone, Law School Legal Aid Clinics, 3 J. LEGAL EDUC. 535, 544 (1951).
}

39372 U.S. 335 (1963). 
for defendants facing felony charges. The creation of new classes of clients entitled to free legal services brought pressure on the bar to meet these needs for services. A ready source of assistance was the socially concerned law student, bored with the tedium of the case-method of instruction, and looking for a way to make the classroom study of law relevant to the real world. As the decade of the 1950's drew to a close, clinical legal education was still viewed as an experimental aspect of the law school curriculum. ${ }^{40}$ That view, however, was soon to change.

In 1959 the Ford Foundation created and funded the Council on Education in Professional Responsibility (COEPR). Between 1959 and 1967, COEPR donated over $\$ 500,000$ to nineteen law schools to start clinical programs. In 1967, the Ford Foundation disbanded COEPR and created in its place the Council on Legal Education for Professional Responsibility (CLEPR). By 1973, some ninety law schools received grants totalling almost $\$ 6,000,000$ from CLEPR to support clinical programs to bring legal services to the poor. The CLEPR initiative and the social fervor of the $60^{\prime}$ s generation of law students, spurred the growth of legal clinical education.

As law schools responded to the demand for social justice, clinical education moved from the margins of the curriculum to a place of recognized value. What was once a fringe element of the law school curriculum was now being main streamed as an area of legitimate scholarly inquiry. ${ }^{41}$ By 1980 when the Ford Foundation terminated its grants to CLEPR, $80 \%-90 \%$ of American law schools offered some sort of clinical program. That same year the AALS, hosted its first conference on clinical teaching. An impressive body of literature emerged as clinical teachers shared their ideas, experiences, and methods in the traditional law reviews and scholarly journals. ${ }^{42}$

Developments in the last decade of the $20^{\text {th }}$ century further solidified the clinical program as a vital part of legal education. In 1989 the ABA Section on Legal Education and Admission to the Bar appointed a task force, chaired by Robert MacCrate, to study the "gap" between the law schools and the practicing bar and recommend ways to narrow the gap. The task force reported in 1992 that the gap was a misperception based upon a misunderstanding of the roles of the law schools

\footnotetext{
40 NeW YORK State Judiclal InStitute, Partners in Justice: A COlloquium ON Developing Collaborations Among Courts, LaW School Clinical Programs and the Practicing Bar, INTRODUCTION TO CLINICAL LEGAL EDUCATION, 7 (2005).

${ }^{41}$ Id. at $12-14$.

$42 \mathrm{Id}$. at $13, \mathrm{n} .59$. For a comprehensive bibliography of clinical legal education see http://law.cua.edu /LexternWeb/ClinicArchive/CLE_Bibliography.pdf (last accessed March 9, 2008).
} 
and the practicing bar in preparing new lawyers to enter the profession. ${ }^{43}$ The task force catalogued for the first time the fundamental skills necessary for the practice of law. ${ }^{44}$ The report noted, however, that law schools could not, nor should they be expected to, fully inculcate all those skills into every graduate. Rather, the task force found that the "skills and values of the competent lawyer are developed along a continuum that starts before law school, reaches its most formative and intensive state during the law school experience, and continues throughout a lawyer's professional career." 45 Noting that the skills training curriculum of most law schools had grown exponentially over the previous four decades, the report specifically singled out clinical programs as having an "important place in the curriculum." 46

The same year the MacCrate Report was published a group of clinical instructors incorporated the Clinical Legal Education Association (CLEA) to promote the development of clinical education and to serve as an umbrella organization for clinical teachers. ${ }^{47}$ In 1994 CLEA began publishing the Clinical Law Review, a peer reviewed journal devoted to furthering clinical legal education.

Subsequent to the publication of the MacCrate Report, the ABA promulgated Standard 301 requiring law schools to maintain an education program "designed to prepare their graduates to participate effectively in the legal profession." 48 While not specifically conditioning accreditation on the availability of clinical opportunities for students, the ABA was at least affirming the value of the clinical programs already in place. In 1996, three years after adopting Standard 301, the ABA amended Standard 302 to require law schools to provide "substantial instruction in: ... (4) other professional skills generally regarded as necessary for effective and responsible participation in the legal profession. ..." 49 That same year the ABA included a provision in the accreditation standards to provide clinical faculty the substantial equivalent to tenure protection traditionally awarded to the

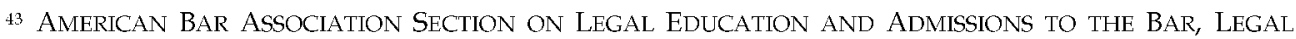

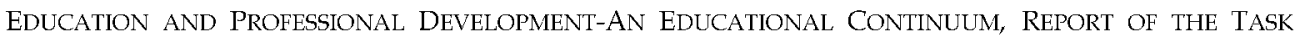
FORCE ON LAW SCHOOLS AND THE PROFESSION: NARROWING THE GAP 3 (1992) [MACCRATE REPORT].

44 Id. at $138-140$.

$4 \overline{1}$ Id. at 3 .

$461 d$. at 6.

47 See http:/ / www.cleaweb.org/index.html (last accessed March 9, 2008).

${ }^{48}$ AMERICAN BAR ASSOCIATION STANDARDS FOR APPROVAl OF LAW SCHOOLS STANDARD 301 (Aug. 1993).

${ }^{49}$ Id. at STANDARD 302(a)(4) (Aug. 1996).
} 
academic faculty. ${ }^{50}$ Additionally, accreditation standards require law schools to "offer substantial opportunities for: (1) live-client or other real-life practice experiences...." 51 These changes to the accreditation standards recognized the value of clinical programs and insured clinical education would be a staple of the American law school experience.

\section{Essential Lawyering Skills and Values}

The debate over the skills and values required to be an effective lawyer is as old as the profession itself. The history of legal education in the United States is a refection of that debate. While much has been written about the fundamental skills and values needed to practice law, there is no agreed upon list that all American law schools embrace. ${ }^{52}$ The accreditation standards of the ABA are purposefully broad on this point to allow law schools flexibility and leave room for innovation in this important area..$^{53}$

\footnotetext{
${ }^{50}$ Id. at STANDARD 405(C) (Aug. 1996).

${ }^{51}$ Id. at STANDARD 302(b)(1) (Aug. 1996).
}

${ }^{52}$ William M. Sullivan, Anne Colby, Judith Welch Wegner, Lloyd Bond, \& Lee S. Shuldan, EDUCATING LAWYERS (2007); Kara Abramson, "Art for a Better Life:" A New Image of American Legal Education, 2006 BRIGHAM YOUNG UNIVERSITY EDUCATION AND LAW JOURNAL 227 (2006); Richard A. Matasar, The Rise and Fall of American Legal Education, 49 NEW YORK LAW SCHOOL LAW REVIEW 465 (2005); Brian J. Moline, Early American Legal Education, 42 WASHBURN LAW JOURNAL 775 (2004); Janet Weinstein \& Linda Morton, Stuck in a Rut: The Role of Creative Thinking in Problem Solving and Legal Education, 9 Clinical LAW REvieW 835 (2003); David A. Binder \& Paul Bergman, Taking Lawyering Skills Training Seriously, 10 CLINTCAL L. REV. 191 (2003); Rodney J. Uphoff, James J. Clark, \&Edward C. Monahan, Preparing the New Law Graduate to Practice Law: A View from the Trenches, 65 UnIVERSITY OF CINCINNATI LAW REviEW 381 (1997); Robert C. Cumbow, Educating the 21 $1^{\text {st }}$ Century Lazoyer, 32 IDAHO LAW REvIEW 407 (1996); Thomas Disare, A Lawyer's Education, 7 MARYLAND JOURNAL OF COMTEMPORARY LeGAL ISSUES 359 (1996).

53 "(a) A law school shall require that each student receive substantial instruction in; (1) the substantive law generally regarded as necessary to effectively and responsibly participate in the legal profession; (2) legal analysis and reasoning, legal research, problem solving, and oral communication; (3) writing in a legal context, including at least one rigorous writing experience in the first year and at least one additional rigorous writing experience after the first year; (4) other professional skills generally regarded as necessary for effective and responsible participation in the legal profession; and (5) the history, goals, structures, values, rules, and responsibilities of the legal profession and its members. (b) A law school shall offer substantial opportunities for: (1) live-client or other real-life practice experiences, appropriately supervised and designed to encourage reflection by students on their experiences and on the values and responsibilities of the legal profession, and the development of one's ability to assess his or her performance and level of competence; (2) student participation in pro bono activities; and (3) small group work through seminars, directed research, small classes, or collaborative work. Standard 302, Curriculum, STANDARDS FOR APPROVAl OF LAW SCHOOls 2006-2007, AMERICAN BAR ASSOCIATION. 
Perhaps the most ambitious attempt to catalogue the skills and values desired in lawyers was the 1992 MacCrate Report. The Task Force on Law Schools and the Profession recognized "it was not possible to 'bridge' or 'narrow' the alleged 'gap' between law schools and the practicing bar without first identifying the fundamental skills and values that every lawyer should acquire before assuming responsibility for the handling of a legal matter." 54 Accordingly, the Task Force devoted a substantial part of their effort to analyzing the profession and developing a list of skills and values each member of the profession should possess. This process resulted in a list of ten skills and four values. ${ }^{55}$ While these skills and values, the Task Force found, are essential to the practice of law, it did not think law schools were solely responsible for their transmittal to lawyers. ${ }^{56}$ Thus, the development of these skills and values are a joint undertaking by the legal academy and the practicing bar. The debate is, and has always been, how should the responsibility for inculcating these skills and values be apportioned between the academy and the bar? The following paragraphs will briefly address each of these skills and values. For a comprehensive treatment of this topic the reader is referred to the MacCrate Report itself.

The first essential skill identified by the Task Force was Problem Solving. ${ }^{57}$ In many respects the practice of law is a process of solving the problems in which clients find themselves. That's why people hire lawyers. To be an effective problem solver, the lawyer must first be able to identify and diagnose the problem. This first step is followed by developing various solutions and strategies to address the problem. After evaluation of the options available, the lawyer must then develop and implement a plan of action to address the problem. During the entire process the lawyer must keep the planning process open to new information and be receptive to new ideas to make sure the ultimate solution is the best available for the client's needs.

Another essential lawyering skill is Legal Analysis and Reasoning.58 No two cases are ever exactly alike and the law is too vast and complex for any lawyer to know all the law. Thus, legal analysis and legal reasoning are critical to identifying legal issues, developing legal theories appropriate to the case at hand, evaluating

\footnotetext{
${ }^{54}$ MACCRATE REPORT, supra note 45 , at 7.

55 Id. at $135-221$.

$56 I d$. at 3 .

${ }^{57}$ Id. at 138 .

58 Id.
} 
competing or alternative legal theories, and criticizing and synthesizing legal arguments.

Closely related to the previous skill is the skill of Legal Research. ${ }^{59}$ A lawyer must know the nature of both legal rules and legal institutions and the ability to use the fundamental tools of legal research to bring the problem solving and legal analysis and reasoning skills to bear on the problem at hand.

The fourth essential skill identified by the Task Force is Factual Investigation.60 Most cases are fact-dependent. Without a thorough knowledge and appreciation of the factual setting in which a particular legal dispute arises, the lawyer simply cannot offer sound advice. Thus, a lawyer must be able to plan an appropriate factual investigation, implement the investigation plan, organize and store the information acquired in a manner that is readily accessible, and to evaluate the factual information developed to determine when the factual investigation should be deemed complete.

Communication is the next essential skill of the lawyer. ${ }^{61}$ Obviously, effective oral and written communications skills cannot be over emphasized. Furthermore, the lawyer must be able to take complex legal concepts and communicate them to lay clients of various depths of sophistication. This requires understanding the perspective of the client and the ability to relate to and communicate with the client in a way that clarifies rather than complicates the matter.

A lawyer's interaction with a client often requires the skill of Counselling. ${ }^{62}$ Indeed, the traditional title of an American lawyer is Attorney and Counsellor at Law. The certificate of admission to practice before the Supreme Court of the United States proclaims that the person has been "duly admitted and qualified as an Attorney and Counsellor of the Supreme Court of the United States." To function appropriately as a counsellor the lawyer must be able to establish a counselling relationship with the client that is appropriate to the nature and scope of the lawyer's role. It is often in the exercise of the skill of counselling that the skills of problem solving, legal analysis and reasoning, legal research, factual investigation, and communication all come together to guide the client to an appropriate solution to the legal problem at hand.

\footnotetext{
${ }^{59} \mathrm{Id}$

${ }^{60} \mathrm{Id}$. at 138-139.

${ }^{61} I d$. at 139 .

${ }^{62}$ Id.
} 
The skill of Negotiation is another critical tool the lawyer must possess. ${ }^{63}$ Negotiations may arise in either a transactional or dispute resolution context. In either case, the lawyer must know how to prepare to negotiate the matter and be able to conduct an effective negotiation session.

Historically, the common law jury trial has been the prevailing means of dispute resolution in the United States. In recent decades the expense of resolving disputes through a full-blown jury trial has given way to various alternative means of resolving conflicts. Thus, arbitration, mediation, administrative adjudication, as well as straight-forward settlement negotiations have all become the more common way of settling civil disputes. The skills applicable to Litigation and Alternatioe Dispute Resolution Procedures are essential skills for the practicing lawyer. ${ }^{64}$ Exercise of these skills requires a working knowledge of the fundamentals of litigation at the trial court level, litigation at the appellate court level, administrative procedures, arbitration, and mediation.

The preceding eight skills are directed at the common task areas of law practice. But, without the skill of Organizing and Managing Legal Work the other skills cannot, from a client's perspective, be applied very effectively. ${ }^{65}$ This skill moves the lawyer from attorney and counsellor to manager or businessman. The skills and concepts required for efficient operation and management of a law practice include, goal setting and effective practice management, developing and implementing systems and procedures to ensure the firm's time, resources, and efforts are allocated efficiently, developing and implementing systems to ensure the legal work is completed within the necessary timeframe, developing and implementing systems to effectively manage the firm's human resources, and developing systems and procedures to effectively and efficiently administer the overall operation of the law office.

The tenth essential skill identified by the Task Force, but certainly not the least important, is the skill of Recognizing and Resolving Ethical Dilemmas that will inevitably arise in the practice of law. ${ }^{66}$ The lawyer must be familiar with the scope, nature, and source of the governing ethical standards and the means or procedures through which these standards are enforced. Identifying ethical questions and

\footnotetext{
$63 \mathrm{Id}$

$64 \mathrm{Id}$.

$6 \overline{I d}$. at 140 .

66 Id.
} 
resolving them quickly and appropriately must be a well developed skill in any competent lawyer.

After setting out the ten essential lawyering skills the Task Force identified four core values that every competent lawyer must embrace. The first value is the Provision of Competent Representation. ${ }^{67}$ Because the practice of law is a profession dedicated to serving the needs of others, lawyers must reach a level of competence in the area or field in which he or she practices. They must then maintain that level by keeping abreast of changes in the law and represent their clients competently.

Striving to Promote Justice, Fairness, and Morality is a value to which all lawyers must be committed. 68 The legal profession bears a special responsibility for the quality of justice in a society. To be a lawyer in such a system requires one to promote justice, fairness, and morality in one's daily practice, as well as in the system at large. This value leads members of the profession to ensure that adequate legal services are provided to those who cannot afford to pay for them. Justice should not be available to just the highest bidder. Similarly, lawyers should contribute to the profession's fulfilment of its responsibility to expand and enhance the capacity of law and legal institutions to do justice.

One privileged to enter the legal profession should Strive to Improve the Profession. ${ }^{69}$ Because the legal profession is self-governing, lawyers must participate in activities aimed toward improving the profession as a whole, assist in the training and development of new lawyers, and work toward eliminating from the profession bias and discrimination that denies others equal rights and opportunities.

The fourth value identified by the Task Force is Professional Self-Development. ${ }^{70}$ Every member of the legal profession must be a perpetual student seeking to improve his or her knowledge and skills. As individuals improve and develop, the profession, the quality of legal services, and justice itself will improve.

\section{Taxonomy of Law School Clinics}

Broadly defined, clinical legal education is teaching lawyering skills and values through experiences that require the student to "do like a lawyer" rather than to

\footnotetext{
${ }^{67} \mathrm{Id}$

$68 \mathrm{Id}$.

${ }^{69} \mathrm{Id}$. at 141 .

70 Id.
} 
just think like a lawyer. These experiences can take various forms and clinics can be described and categorized by the approach taken. Typically, clinical or experience based legal education is categorized as simulation, live client (in-house) clinics, or externships. ${ }^{71}$ The basic differences between them are: "in simulationbased courses, students assume professional roles and perform law-related tasks in hypothetical situations; in in-house [live client] clinics, students represent clients or perform other professional roles under the supervision of members of the faculty; and in externships, students represent clients or perform other professional roles under the supervision of practicing lawyers or they observe or assist practicing lawyers or judges in their work." 72 The following paragraphs address each of these in more detail. ${ }^{73}$

\section{Simulation}

Perhaps the oldest form of clinical education used in American law schools is the familiar simulation exercise. ${ }^{74}$ Students are placed in various roles, e.g., plaintiff's lawyer, defence lawyer, etc., and given a problem that requires them to apply legal theory, as well as lawyering skills and values to resolve the problem in the best interests of their client. Perhaps the most common form of simulation clinical legal education is the familiar moot court exercise used in every law school in America. In this form of clinical legal education, students represent their clients before an appellate tribunal and argue their respective sides of the case to a panel of lawyers, law professors, or even other students, who play the roles of appellate judges. The exercise usually requires students to research the legal issues using the research skills learned in an earlier legal research course. They must then apply the writing skills learned in their legal writing course to prepare and file a brief supporting their position in the court. Finally, they present oral arguments to the court seeking to either sustain or reverse the decision of the lower court, depending upon their particular role in the problem. The judges, of course, pepper the student advocates with questions from the bench that require quick thinking and analysis. A critique of the process reinforces good skills and values and identifies those areas in which

\footnotetext{
${ }_{11}$ Roy Stuckey, Teaching with Purpose: Defining and Achieving Desired Outcomes in Clinical Law Courses, 13 CLINICAL L. REV. 807, 812 (2007).

${ }^{72} I d$.

${ }^{73}$ Clinical programs can also be categorized by the area of law in which they operate, by whether their goal is to work toward law reform in a given area, or whether they seek to further a particular social justice mission. Addressing these salutary aspects of clinical legal education is beyond the scope of this article.

${ }^{74}$ As early as 1779 , George Wythe of the College of William and Mary used Moot Court exercises and Mock legislative sessions to supplement his classroom lectures. MCMANIS, supra note 7, at 601-602.
} 
the student needs additional improvement. A moot court exercise brings together the thinking, researching, writing, and advocacy skills required of a lawyer representing clients before appellate courts. While the context is the appellate phase of the judicial process, the skills developed are transferable to other aspects of legal practice.

Simulations are commonly used to teach trial advocacy skills. All American law schools offer some sort of trial practice or trial advocacy simulation exercise. A few schools include this sort of clinical experience as part of the required curriculum. ${ }^{75}$ These courses normally take the form of various courtroom vignettes requiring the student to conduct a direct examination of a witness, cross examine a witness, introduce various exhibits, deliver opening statements and closing arguments to a jury, object to evidence offered by an opponent and respond to those objections, all under the supervision and direction of an experienced trial lawyer. A complete mock trial is often the capstone of this sort of simulation. Feedback and critique by the instructor reinforces strengths and identifies weaknesses. In addition to learning the skills necessary to present and oppose evidence offered in the typical American trial, this sort of experience requires the student to draw upon doctrinal courses such as evidence, civil or criminal procedure, and/or the substantive law of torts, contracts, crimes and defenses, depending upon the nature of the simulation, and assess, analyze, and apply these rules, principles, and theories to the problem facing a simulated client.

The Advanced Trial and Appellate Advocacy course at Campbell University School of Law takes this moot court exercise and the basic trial skills course to a new level. Offered to third-year students, the course begins by pairing the students into twoperson law firms. Each firm is then assigned to represent a party in a mock civil case. The instructors for the course provide information about the facts of the dispute to other students who volunteer to play the roles of clients and witnesses. The lawyers must then interview their client and learn the facts of the incident and recommend an appropriate course of action. As the course progresses over the entire academic year, the students receive classroom instruction on various aspects of civil litigation, such as interviewing, taking depositions, conducting discovery, drafting pleadings, and other matters. They then apply those principles to the practical problem of representing their client in the case.

Over the course of the year, the students will interview their client, draft and file appropriate pleadings, conduct informal discovery, conduct discovery from the

\footnotetext{
$7 \overline{5}$ Campbell University School of Law, where one of the authors teaches, requires all students to participate in both a moot court experience and trial advocacy as part of the required JD curriculum.
} 
opposing party, including taking the deposition of the opposing party, participate in a mediated settlement conference, prepare a joint pre-trial order, participate in at least one pre-trial conference, file and argue motions, as appropriate, prepare and submit proposed jury instructions, and try the cases to a jury of second year law students with an experienced trial lawyer acting as the judge. The verdict winner at trial will file the judgment with the court and the loser at trial will file a notice of appeal from that judgment. The parties will then settle the record on appeal, brief the assignments of error, and argue the case before an appellate panel composed of other students in the course. The appellate panel prepares and publishes the opinion of the court of appeals. All the pleadings and court filings are filed using the e-filing system used by the North Carolina Business Court, a division of the North Carolina Superior Court, the trial court of general jurisdiction in the state.

The instructors in this year-long simulation act as senior partner, judge for motions and pre-trial matters, mediators, and various sources of information available through informal discovery. In many respects, this course is a capstone experience for law school. The students must pull from their doctrinal courses taken during the first two years of school and apply those principles to protect their client's interests in the litigation. They also experience areas of law, practice, and procedure they have not had in a formal course and must research and apply their own critical thinking and problem solving skills to appropriately address these areas. Importantly, they must work with their own trial partner, as well as collegially and cooperatively with opposing counsel, while zealously representing the legitimate interests of their fictional client. They quickly learn the importance of professional relationships and the difficulties that arise when promises are made and not kept or communications and expectations are not made clear. While the course covers trial and appellate practice from beginning to end, perhaps the most valuable aspect of this simulation is that the students get to experience the consequences of their decisions and actions at various stages of the process. For example, a student who fails to develop a particular fact during discovery finds himself precluded from offering this key fact at trial. In this respect, the instructors respond to properly submitted requests for information, such as medical records or business records from a non-party. If the students do not properly seek those facts, they simply do not get them and they proceed to trial without it. Similarly, if a student fails to object to proffered evidence at trial or fails to make the appropriate argument at trial, she will find herself precluded from advancing the appropriate argument before the court of appeals. The vast majority of students who take the course report that enduring the consequences of their decisions and actions is the most valuable learning experience. The simulation allows students to make mistakes, deal with the consequences, learn their lesson, and refine their lawyering skills and values in a "safe" environment without actually jeopardizing the rights of a real client. 
While law schools use simulation clinics routinely to teach trial and appellate advocacy skills, they are adaptable to transactional practice, as well. In fact, the simulation model can be adapted to any number of non-litigation skills. For example, one way to teach contract drafting is described by Prof. Charles Lewis of Campbell University School of Law:

I decided to teach contract drafting by integrating it within the setting of an ongoing law practice, where the lawyer has a client to be interviewed, consulted, advised, and kept up to date, as well as a senior partner who supervises the work, an associate with whom to work, and opposing lawyers with whom the contract must be negotiated successfully. I wanted the students to confront and learn to handle the legal, ethical, and other issues that confront practicing lawyers. In short, I wanted to teach contract drafting the same way I learned it - not by reviewing drafts or drafting them in class, but by drafting a contract in the same fashion as a lawyer in practice.

Instead of having students make up the facts for the project as in the previous course, I would require that they wrestle the facts out of a simulated client interview, just as practicing lawyers must do. Instead of having students draft in class a contract conforming perfectly to a client's interests, I decided to put the students through a simulated negotiation process that involved opposing lawyers (students) representing the other client's interests, a process that would result not in the perfect contract but in the best contract under the circumstances.

I also wanted the students to experience those working relationships that shape their work in the law practice. In the existing course design, they experienced working with another person in the project because I assigned two students to represent each client, but I also wanted them to experience a working relationship with a senior partner who assigns and supervises their work, discusses issues and possible solutions, and reviews and critiques 
contract drafts. I also wanted them to have a continuing relationship with the client and also with the lawyers (students) representing the client on the other side of the contract.

Finally, I wanted the students to use an office file to document the work that a practicing lawyer does in planning, drafting, and negotiating a contract. I wanted the file to reflect their working relationship with their senior partner, their student partner, the client, and the opposing lawyers, to show how the students handled the ethical and legal issues that inevitably arise in the drafting of a contract, and to reflect how they protected themselves from the threat of legal malpractice or ethical malfeasance. ${ }^{76}$

Prof. Lewis' approach is adaptable to any number of law practice issues. Real property transactions, estate planning, elder law issues, and just about anything else you can think of could be put in the setting of a simulated law practice.

The key to effective simulated clinical experiences is a small faculty/student ratio. To provide adequate guidance, to insert appropriate roadblocks, ethical issues, and other problems for the student to solve, and to insure the development of interviewing and negotiation skills, the instructor must have sufficient time to spend with the student as the senior partner, client, judge, mediator, or mentor. A small faculty/staff ratio and the ability to control the simulation to insure certain issue, skills, and values are adequately addressed make simulation clinics a very effective methodology. Apart from the need to provide adequate numbers of faculty for the size of the class, the costs involved are essentially the same as traditional classes.

\section{Live Client Clinics}

Live client clinics, often referred to as "in-house" clinics because they are housed in the law school, places the law student in the actual role of lawyer instead of asking her to play the role of a lawyer. Instead of simulated problems and actors or other students assuming the roles of client and witnesses, real people with real stories and real legal problems provide the context within which the law student can learn

\footnotetext{
${ }^{76}$ Charles C. Lewis, the Contract Drafting Process: Integrating Contract Drafting in a Simulated Law Practice, 11 CLINICAL L. REV. 241, 244-245 (2005).
} 
how to practice law. Because law students are not lawyers but the clients are real people with real problems, clinical directors and faculty must closely supervise and monitor the interaction between student and client. A small student/faculty ratio is critical to insuring an optimum educational opportunity in any clinical setting. That holds doubly true when operating in a live client clinic. Like the student in a simulated clinic, a student in a live client clinic needs supervision, observation, critique, and feedback from a qualified teacher to get the most out of the educational opportunity. More importantly, however, in the live client clinic there is a real person who must be competently represented and counselled. Only close supervision by a licensed practitioner who is qualified and competent to practice in the subject area involved can provide the degree of oversight that both protects the interests of the client and creates a meaningful educational opportunity for the student.

Precisely because the live client clinic puts law students in the role of practicing attorneys with real clients it offers an experience that cannot be duplicated by simulated clinics. In this setting, law students must interview real people, sort out the legally significant facts from the facts the client thinks are important, identify the salient issues, determine the appropriate rule of law, craft a legal solution to the problem, and counsel the client on the various options available. One commentator observed:

The most important lessons that can be learned in the client representation courses include many of the same lessons that can be learned through simulations or observations, including the values, behaviors, attitudes, and ethical requirements of a lawyer (professionalism). However, the learning is deeper and more meaningful when a student is participating as a lawyer, rather than as an observer or assistant, or in a make believe simulation. This is particularly true of the key values of the profession: the importance of seeking justice and providing access to justice, the reasons for fostering respect for the rule of law, the essentiality of integrity and truthfulness, the need to deal sensitively and effectively with diverse clients and colleagues, and the value of nurturing quality of life in light of the stresses and time commitments of law practice. $^{77}$

\footnotetext{
77 ROY STUCKEY, BeST PRACTICES FOR LEGAL EdUCATION 189-190 (2007).
} 
The live client presents a dynamic that makes the educational opportunity both invaluable and, at the same time, unpredictable. Unlike the simulated clinic where the instructor has total control over the scope and complexity of the problem, the live client clinic is dependent upon the nature of the case that walks in the door. Some cases will be rather simple and straightforward. Some clients will be good historians and good record keepers and have ready access to all the salient facts. Other cases will be more complex. Facts will be lost. Memories will fail. Documents will be missing. The law itself may be unsettled. Of course, those things happen in the real practice of law. But from an educational perspective, the experience of students in a live client clinic will vary depending upon the nature of the case and the client. It will be impossible to insure every student gets the same range of experiences. Furthermore, when the semester ends and the student moves on, the case may not be resolved. The instructor or other students must be able to pick up the case and see it through to conclusion to protect the interests of the client.

The live client clinic, like the simulation experience, is very flexible and can operate in any number of substantive areas. Clinical opportunities are as varied as the practice of law. For example, many U.S. law schools offer one or more of the following types of live client clinics: Criminal Justice, ${ }^{78}$ Environmental Law, ${ }^{79}$ Poverty Law or Legal Aid to the Indigent,, 0 Domestic Violence and Child Protection, ${ }^{81}$ Alternative Dispute Resolution, ${ }^{82}$ HIV/AIDS, 83 Fair Housing, ${ }^{84}$ LowIncome Taxpayer Representation, ${ }^{85}$ Immigration, ${ }^{86}$ Bankruptcy, ${ }^{87}$ Small Business Aid, ${ }^{88}$ Legal Assistance to Servicemembers, ${ }^{89}$ and Juvenile Justice. ${ }^{90}$

\footnotetext{
${ }^{78}$ Yale Law School, http:/ / www.law.yale.edu/academics/1218.asp (last accessed March 9, 2008).

${ }^{79}$ Harvard Law School, http://www.law.harvard.edu/academics/clinical/clinics.htm\#environmental (last accessed March 9, 2008).

${ }^{80}$ Pepperdine University School of Law, http://law.pepperdine.edu/clinical/legal_aid_clinic.html (last accessed March 9, 2008).

${ }^{81}$ University of Texas School of Law, http://www.utexas.edu/law/academics/clinics/domestic/(last accessed March 9, 2008).

${ }^{82}$ North Carolina Central University School of Law, http://web.nccu.edu/law/dri/index.html (last accessed March 9, 2008).

${ }^{83}$ University of the District of Columbia, David A. Clarke School of Law, http:/ / www.law.udc.edu/programs/hiv/index.html (last accessed March 9, 2008).

${ }^{84}$ The John Marshall Law School, http://www.jmls.edu/fairhousingcenter/fairhousingclinic.shtml (last accessed March 9, 2008).

${ }^{8 \overline{5}}$ Duke University Law School, http://www.law.duke.edu/litc/index (last accessed March 9, 2008).
} 
The typical live client clinic is supervised by a licensed practitioner who is experienced in the particular substantive area and who is also a member of the school's law faculty. Each clinical supervisor generally has six to ten law students under his or her supervision at any given time. The clinic itself is basically a small law firm dedicated to a particular specialty area or clientele and the clinical supervisor acts as the senior partner and is responsible for the quality of the legal services rendered. Unlike the typical small law firm, the clinical director is also a teacher who is responsible for monitoring and assessing student performance and providing meaningful feedback so necessary to develop the skills and values the student will need to be a successful lawyer.

Because law students in live client clinics are representing real people, live client clinics must be cognizant of the rules concerning the unauthorized practice of law in the particular jurisdiction and the need for professional liability protection. ${ }^{91}$ Typically, professional licensure is conditioned upon graduation from an accredited law school, passing the bar examination administered by the state authorities, and possessing the requisite character and fitness to enter the legal profession. ${ }^{92}$ Rendering legal advice, representing a person before a court or other tribunal, drafting wills, mortgages, trusts, or other legal documents, or otherwise "practicing law" without having been admitted to the practice of law in a given jurisdiction is generally prohibited. ${ }^{93}$ Obviously, law students have not graduated from law school, have not passed the bar exam, and have not been admitted to the

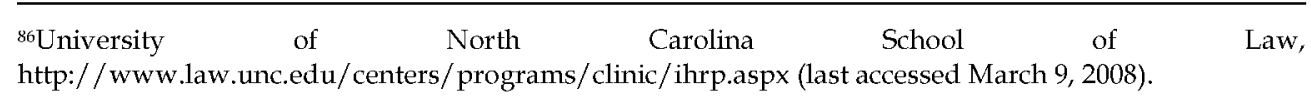

${ }^{87}$ Brooklyn Law School, http:/ / www.brooklaw.edu/academic/courses/description/?course=L_509 (last accessed March 9, 2008).

${ }^{88}$ Chicago-Kent College of Law, http://www.kentlaw.edu/academics/clinic/startuplaw.html (last accessed March 9, 2008).

${ }^{89}$ George Mason University School of Law, http:/ / www.law.gmu.edu/clinics/clas (last accessed March $9,2008)$.

${ }^{90}$ Campbell University, Norman Adrian Wiggins School of Law, http://aw.campbell.edu/pubs /jjp.html (last accessed March 9, 2008).

${ }^{91}$ For a discussion of the ethical and legal competency issues that arise in the live client clinical setting,
see Peter A. Joy and Robert R. Kuehn, Conflict of Interest and Competency Issues in Law Clinic Practice, 9
CLINICAL L. REV. 493 (2002).
92 See, e.g., N.C. GEN. STAT. \$ 84-24 (2005); RULES GOVERNING ADMISSION TO THE PRACTICE OF LAW IN THE
STATE OF NORTH CAROLINA .0500 (2006).

93 See, e.g., N.C. GEN. STAT. § 84-4 (2005). 
practice of law. To avoid the general prohibition against practicing law without a license, legal clinics are typically granted special dispensation to permit law students to engage in the very limited practice in the clinic under the supervision of the licensed practitioner who directs the clinic. ${ }^{94}$ The supervising lawyer is, of course, responsible not only for the quality of legal services rendered but for insuring the law students working in the clinic conform to the ethical rules and regulations of the jurisdiction. ${ }^{95}$

Another aspect of live client clinics that deserves attention is the question of professional liability insurance coverage for the clinic supervisors and the law students. Obviously, the lawyer-supervisor owes a professional duty to the clients in the clinic, the breach of which gives rise to a professional liability claim. While there is only one reported instance of a malpractice claim against a law school clinic and the director, and that claim was dismissed, the potential for professional liability is still present. ${ }^{96}$ Prudence dictates insurance coverage for the clinic director, especially when considering the supervisory responsibility the director has for the work product of the law students under his supervision. But what about the law students themselves? As non lawyers are they personally liable for advice or services they dispense? There is ample authority that non lawyers who purport to offer legal advice are subject to claims of legal malpractice. ${ }^{97}$ The very purpose of placing law students in a live client clinic is to give them experience in the practice of law. The valuable experience they gain by representing real clients comes with a price: the exposure to professional liability for negligence in the delivery of legal services. In reality, however, that price is negligible. Though there are no reported cases of professional liability claims against law students working in law school clinics, prudence dictates some sort of professional liability protection even though the exposure is quite limited..$^{98}$

\footnotetext{
94 See, e.g., N.C. GEN. STAT. \& 84-8 (2005); 27 N.C. AdMIN CODE 1 C.0200 (2006).

${ }^{95}$ In re Wilkinson, 805 So. 2d 142 (La. 2002) (Licensed attorney responsible for incorrect legal advice given to client by law student); Cf. MODEL RulES OF PROF'L CONDUCT R. 5.3 cmt. (1) (2002) ("A lawyer must give ... [non lawyer] assistants appropriate instruction and supervision concerning the ethical aspects of their employment, particularly regarding the obligation not to disclose information relating to representation of the client, and should be responsible for their work product.")

96 Juengain v. Johnson, 571 So. 2d 167 (Ct. App. La. 1990).

${ }_{97}$ Buscemi v. Intachai, 730 So. 2 d 329 (Fla. App. 1999); Webb v. Pomeroy, 655 P. 2 d 465 (Kan. App. 1982); Mattieligh v. Poe, 356 P. 2 d 328 (Wash. 1960).

98 Professors Peter Joy and Robert Kuehn report that professional liability carriers do not generally segregate claims data in such a way to isolate claims against clinical programs or participants. Furthermore, their contact with representatives of the professional liability insurance industry revealed that the potential for malpractice claims against clinics are very low due to the nature of the cases
} 


\section{Externships}

Externships, like the in-house clinic, place the law student more directly in the role of lawyer. Instead of working out of a law firm housed in the law school and directed by members of the law school faculty, the student in an externship works under the tutelage of a private practitioner, corporate legal counsel, lawyers in a government agency, or judge. Essentially, externships

place students in various kinds of legal jobs ... where they perform legal work under the supervision of a lawyer in the agency. Many schools try to create a three-way relationship between professor, student, and supervisor so that the faculty member can monitor the student's work and the supervisor's evaluation of it. Other schools rely on the student's reflections upon the work in the externship as fodder for learning. In most externship programs, students write reflective journals, have tutorial meetings with faculty, and participate in seminar discussions. Learning goals of externships include providing students with a milieu within which to learn a substantive area in depth while developing a critical perspective on the organization of legal work. Externship teachers often explore the ethical dimensions of the student's experiences and observations, as well as explore the justice issues that are inherent in most of the settings in which students practice. ${ }^{99}$

While the work performed by the student in an externship and in a live-client clinic may be essentially the same, the first line supervisor in the externship is not a member of the school's law faculty. Typically, the externship supervisor is primarily interested in solving the legal problem in front of her and offers the law student an opportunity to accompany her on that journey. While the law student is in the position to observe and participate in the legal practice, the primary objective

undertaken by the clinics. Peter A. Joy and Robert R. Kuehn, Conflict of Interest and Competency Issues in Law Clinic Practice, 9 CliniCAL L. ReV. 493, n. 45 (2002).

99 Elliott S. Milstein, Clinical Legal Education in the United States: In-House Clinics, Extemships, and Simulations, 51 J. LEGAL EDUC. 375, 380 (2001). 
of the field supervisor is to deliver legal services to the client, not teach the law student. Accordingly, close coordination and cooperation between the law school's clinical faculty and the externship supervisor is important to insure the maximum educational experience for the student. One commentator recognized this critical interface and observed:

In externships, supervision has a complex form, involving an "allocation of academic tasks" that generally identifies assignment, preparation, guidance, and task-specific feedback as responsibilities of the field supervisor, while placing some aspects of supervision, notably critique of the legal practice and context, in the hands of the law school faculty. There is an ongoing vigorous debate among externship faculty about the proper relationship between faculty and field supervisors and how they should establish and communicate teaching expectations. ${ }^{100}$

Obviously, the overall value and effectiveness of the externship as an education experience is dependent upon how the faculty and the field supervisor allocate the critical educational tasks. The ABA recognizes the unique challenges of integrating the field placement experience in the broader educational program of the law school and specifically addresses it in the accreditation standards. ${ }^{101}$ Specifically, externships must have "a clear statement of the goals and methods, and a demonstrated relationship between those goals and the methods ...."102 Schools must also devote "adequate instructional resources" to supervising the externship and develop and publish a "clearly articulated method of evaluating each student's academic performance..." in a manner that involves both the field placement supervisor and the responsible faculty member. ${ }^{103}$ Equally important, the externship program must have "a method for selecting, training, evaluating, and communicating with field placement supervisors ... [and] opportunities for student reflection on their field placement experience, through a seminar, regularly scheduled tutorials, or other means of guided reflection." 104

\footnotetext{
${ }^{100}$ Harriet N. Katz, Reconsidering Collaboration and Modeling: Enricling Clinical Pedagogy, 41 GONZAGA LAW REVIEW 315, 327 (2006).

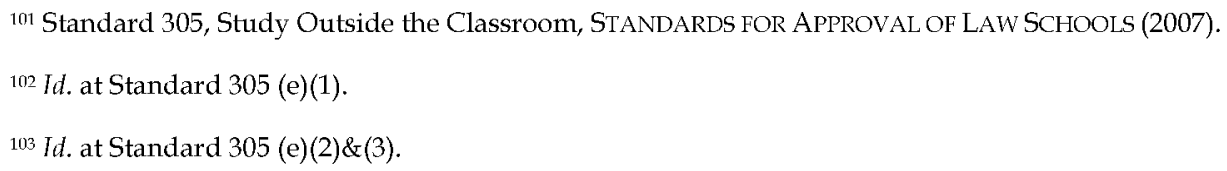


Carefully selected externships with trained and committed field supervisors, working closely with a faculty member, offer unique opportunities for law students to experience the practice of law "up close and personal." In this regard, externship could be superior to the in-house clinic. While the in-house clinic serves real clients with real problems, it is still a creation of the education establishment and exists fundamentally as a way to train law students for the practice of law. Externships, on the other hand, are on-going law practices that exist to practice law. The law student is permitted to observe the details of that operation as it actually works and to varying degrees participate in the delivery of legal services in that context.

\section{The Continued Viability of American Clinical Legal Education}

As early as 1917 when William Rowe first raised the issue of training lawyers for practice through clinical experience, the legal academy has discussed and debated the viability of clinics as part of the law school curriculum. ${ }^{105}$ Some argue that law school is supposed to teach the law student how to think like a lawyer and the bar is responsible for teaching the new lawyer how to practice law. ${ }^{106}$ Others assert the goal of a legal education should be to prepare the neophyte lawyer to enter a profession with the skills needed to perform like a lawyer. ${ }^{107}$ The dramatic increase in clinical programs at American law schools in the latter decades of the $20^{\text {th }}$ century indicates the legal academy has come to appreciate its responsibility to develop the law student intellectually and professionally. That said, clinical legal education is still at the margins of the curriculum in most American law schools. Few schools require students to participate in a clinical program as a requirement for graduation. While schools generally report they have sufficient clinical offerings for all who wish to participate, there is often no institutional encouragement to enroll in clinical courses. The doctrinal courses and the casebook method are still the staples of main stream legal education well into the first decade of the $21^{\text {st }}$ century.

Analyzing the pros and cons of clinical education can be an exercise in question begging. If one views the primary role of law school as purely an intellectual exercise in which the student reads and analyzes appellate court opinions, as

\footnotetext{
${ }^{105}$ William V. Rowe, Legal Clinics and Better Trained Lawyers - A Necessity, 11 ILL. L. REV. 591, 607 (1917).

106 Rodney J. Uphoff, James J. Clark, and Edward C. Monahan, Preparing the New Law Graduate to Practice Law: A View from the Trenches, 65 U. CIN. L. REV. 381, n.3 (1997) (collecting articles discussing the legal academy's general anitpathy toward the practice of law and the failure to adequately prepare law students for law practice.)

${ }^{107}$ Robert C. Cumbow, Educating the 21st Century Lawyer, 32 IDAHO L. REV. 407 (1996).
} 
Langdell advocated, clinics are expensive, wasteful, and counter-productive. If, on the other hand, law schools are professional schools with the goal of preparing students to practice law, clinics are indispensable and no student should graduate without a clinical experience. The reality is that main stream legal education has a foot in both camps. The recently published report by the Carnegie Foundation for the Advancement of Teaching found a necessary role for both types of legal learning:

The two types of legal knowledge - the theoretical and the practical -- are complementary. Each must have respected place in legal education. Further, each sort of knowledge, with its own characteristic setting and ways of teaching, can be made to advance when it is understood in relation to its complement, so that neither remains what it would be if it continued to develop in isolation. This process of mutual development will progress best when it is directed by a focus on the professional formation of law students. Amid the useful varieties of mission and emphasis among American law schools, the formation of competent and committed professionals deserves and needs to be the common, unifying purpose. A focus on the formation of professionals would give renewed prominence to the ideals and commitments that have historically defined the legal profession in America. ${ }^{108}$

The Carnegie Foundation report advocated an integrative approach to legal education where legal analysis, practical skill training, and development of professional identity are all part of the curriculum. ${ }^{109}$ Legal analysis, a prerequisite for both practical skills and professional identify, can be taught in the traditional classroom setting. ${ }^{110}$ Practical skills and professional identity, on the other hand, are not so susceptible to pure classroom learning. Practical skills are best "developed through modelling, habituation, experiment, and reflection . . . and frequently requires settings and pedagogies different from those used in the teaching of legal analysis." 111 Professional identity is the factor that should unify

\footnotetext{
108 William M. Sullivan, AnNe Colby, Judith Welch Wegner, Lloyd Bond, \& Lee S. Shulman, EDUCATING LAWYERS 13 (2007).

${ }^{109} 1$ Id.

110 Id. at 14 .

${ }^{1111} \mathrm{Id}$.
} 
the classroom and clinical components and is the "catalyst for an integrated legal education." 112

From 2001 to 2007 the Clinical Legal Education Association conducted a study of best practices for legal education. Through a number of drafts, meetings, symposia, and discussions the authors developed a comprehensive set of recommendations to guide individual teachers and curriculum developers to enhance legal education in the United States. The project begins with the proposition that the purpose of legal education is to "effectively prepare students for practice." 113 To accomplish this goal, law school curricula should "develop knowledge, skills, and values progressively; integrate the teaching of theory, doctrine, and practice; and teach professionalism pervasively throughout all three years of law school."114 An entire chapter of the book is devoted to best practices recommendations for experiential courses.115 Specifically addressing the value of clinical education, the study concludes: "Experiential education is a powerful tool for forming professional habits and understandings. We encourage law schools to expand it use."

With the expansion of clinical offerings in the last decades of the $20^{\text {th }}$ century and recognition of the value of experiential education in the law school curriculum by both the Carnegie study and the Best Practices project, it is safe to say that clinical legal education has earned its place in American legal education. The development of a large body of scholarship devoted to clinical pedagogy warrants respect even from those in the academy who are solely theoretical and research oriented.117

Perhaps the main obstacle to an even greater expansion of clinical legal education in the coming decades is the cost factor. With its low student to faculty ratio, so necessary for adequate supervision, clinics require more fiscal resources than traditional classroom subjects. Langdell's case method approach "seemed to work as well with two hundred students as it did with twenty" and, no doubt, fostered an attitude among university administrators that law schools were inexpensive and

\footnotetext{
${ }^{112} / d$.

113 ROY STUCKey, BeSt PRACTICES FOR LEGAL EDUCATION 1 (2007).

114 Id. at $8-9$

115 Id. at $165-205$.

116 Id. at 167.

117 J.P. Ogilvy and Karen Czapanskiy, Clinical Legal Education: An Annotated Bibliography (Revised 2005), http://faculty.cua.edu/ogilvy/Biblio05clr.htm (last accessed March 9, 2008).
} 
would generate considerable income for the university. ${ }^{118}$ Since the late 1990 's when the last source of government and large private grants for clinical programs ended, schools have been faced with the difficult task of reallocating current resources or developing new sources of funding. ${ }^{119}$ Solving the funding question will, most likely, be the critical factor in whether clinics expand or stagnate in the coming decades.

In an article published in 2000, Professors Margaret Barry, Jon Dubin, and Peter Joy reviewed the historical developments of clinical legal education and mused about its future:

Clinics are beginning to be understood within the academy as embracing a method that finds its expression in a variety of experiential contexts, but is driven by pedagogical goals that transcend the specific subject matter. Thus, it is dawning on the academy that a student who takes part in a domestic violence clinic is not being trained as a practitioner in [just] that area. The student learns about lawyering skills such as interviewing, counselling, negotiation, trial advocacy, and case management; technological resources; ethical considerations; political and structural influences; the role of social science, psychology and racial, cultural and economic forces; and the lawyer's role as a force for extracting services from and changing the process. In other words, the student is learning how to be an effective problem solver for clients - a skill that recognizes the value and limitations of the law and its place in the complex contexts of our rapidly changing world. The student also learns the importance of reflecting on every aspect of practice, each decision that is made, and how each step is carried out as a part of the clinical experience. Law schools will not fulfil their potential if they continue to shunt this multi-layered level of guided experiential learning into a narrow category of skills instruction or associate a clinical experience with a

\footnotetext{
${ }^{118}$ ROBERT STEVENS, LAW SCHOOL, LEGAL EDUCATION IN AMERICA FROM THE 1850'S TO THE 1980'S 268.

${ }_{119}$ Margaret Martin Barry, Jon C. Dubin, and Peter A. Joy, Clinical Education for this Millennium: The Third Wave, 7 CliniCAL L. REV. 1, 28-29 (2000).
} 
specific subject matter. Fortunately, a better appreciation of clinical legal education is dawning. ${ }^{120}$

The findings of the both the Carnegie study and the Best Practices project reveal that Professors Barry, Dubin and Joy were correct: a better appreciation of the value of clinical legal education is dawning.

\section{Transferability of the American Paradigm to the German System}

\section{Competition and Best Practice}

From a German perspective it is both reassuring and somewhat troubling that American legal education is still evolving and debating the best method to train lawyers. Reassuring in the sense that it reflects a continuing effort to produce the best training experience possible. Troubling in that it appears there are no simple answers to this important question. Nevertheless, the on-going debate in America does reveal that US law faculties and curriculum developers are willing to take up new ideas and to integrate them into their educational program.

Currently, the governmental regulation of the traditional German legal education leading to the Erste Staatsexamen restricts the freedom and flexibility of universities to improve their curriculum. The all important Erste Staatsexamen drives the curriculum. By the same token, the uniform nature of the examination restricts competition between universities in curriculum emphasis and offering. Embracing the Bologna Process dual cycle degree structure, however, will result in a fundamental shift towards more freedom and latitude in curriculum development for German universities. This, in turn, should produce more competition between universities. Increased competition will undoubtedly lead to more innovation, choices, and opportunities for both aspiring law students and the legal system itself. Specialized curricula, the development of best practice models, and an ongoing evaluation of the relationship between academic study and the practice of law should all be part of a new dynamic in German legal education.

\section{Integrating Legal Analysis, Practical Skill Training and the Development of Professional Identity}

The traditional German concept of legal education distinguishes between academic education focusing on legal theory and teaching the students "to think" like lawyers and a training program for legal practice (Referendariat) teaching the

\footnotetext{
${ }^{120} \mathrm{Id}$. at 72 .
} 
students "to do" like lawyers. Some schools, however, have sought to add practical training through moot court programs. ${ }^{121}$ But these initiatives do not have a formative influence on the mainstream paradigm of legal education and they are not anchored in the examination regulations. ${ }^{122}$

While the lack of a formalized and required practical component in the curriculum of most American law schools is criticized by many American legal educators and lawyers, the American legal academy has generally recognized the value an integrative approach, combining legal analysis, practical skill training and development of professional identity, has in preparing law students for their professional life as lawyers. Both theoretical and practical knowledge are complementary and can better be understood and developed in relation to each other. Unlike the Referendariat where this important aspect of legal education is turned over to practitioners, bureaucrats, and judges, the American clinical system uses the professor-practitioner as the teacher, mentor, and role model for the student. This permits not only the development of practical lawyering skills, but it also provides the opportunity for the student to reflect and consider, under the tutelage of a legal educator, how this practical experience impacts his or her view of the law and the legal system and to consider how the law or legal system might be changed to better pursue the elusive goal of justice in every case. Thus, the practical informs the theoretical and the theoretical informs the practical resulting in a truly integrative approach. Skills and values essential to the practice of law should be developed along a continuum that starts early in a student's academic education, experienced, evaluated, and reflected upon in light of both academic and practical experience, and continue throughout a lawyer's professional career. A clinical component provides this integrative opportunity.

\footnotetext{
121 See, e.g., Düsseldorf Moot Association, http://www.uni-duesseldorf.de/dma (last accessed March 3, 2008); Juristische Fakultät, Universität Augsburg, http://www.jura.uniaugsburg.de/studium/moot_court.html (last accessed March 3, 2008); Juristische Fakultät der Universität Osnabrück, http://www.jura.uos.de/html/217.htm (last accessed March 3, 2008); Juristische Fakultät der Leibnitz Universität Hannover, http://www.jura.uni-hannover.de/vismoot (last accessed March 3, 2008); Juristische Fakultät der Universität Tübingen, http://www.jura.unituebingen.de/studium/vismootcourt (last accessed March 3, 2008); Institut für Anwaltsrecht an der Humboldt Universität Berlin, http://www.rewi.hu-berlin.de/IfA (last accessed March 3, 2008).
}

122 See JAG NRW, from 11 March 2003 as published on 26 March 2003 GV. NRW. S. 135, lastly altered by statute from 5 November 2004 (GV NRW S. 680); JAPO Bayern, from 13 October 2003, Bayerisches Gesetz- und Verordnungsblatt Nr. 23/2003, S. 758 ff.; NJAG as amended on 15 January 2004, Nds. GVB1. S.8; JAPrO Baden Württemberg, as published on 8 October 2002 (GB1. S. 391), amended by Verordnung des Justizministeriums zur Änderung der Juristenausbildungs- und Prüfungsordnung from 20 April 2005 (GBl. S. 402); JAG Berlin, from 23 June 2003 (GVBl. S. 232), lastly altered by statute from 9 June 2004 (GVB1. S. 237). 
Accordingly, we conclude that it is advisable to give the training of essential legal skills and values its place in the formal German legal education curriculum along with the development of legal analysis, critical thinking, and legal theory. This integrative curriculum should be implemented for all students irrespective of any potential changes in the length or organization of the Referenderiat.

\section{Clinical Legal Education - An Option for German Universities?}

The American system of legal education illustrates that other modern and well developed systems exist that are capable of developing professional identity, analytical and critical thinking skills, as well as practical legal skills at the same time. The German debate about reforming legal education should, therefore, consider whether clinical legal education should become part of the established curriculum, or offered as a new, additional, or alternative type of practical legal education. We think clinical legal education can be successfully incorporated into the current German system for programs leading to the Erste Staatsexamen and Referendariat as well as the already existing juridical Bachelor's and Master's programs.

At the Hochschule Wismar this concept has been employed with success since 2004 . Both the Bachelor's and Master's program require all students to take a clinical course each semester. ${ }^{123}$ These clinical courses simulate legal processing and counselling based on real cases which are edited by the faculty to preserve the anonymity of the people involved. Students are required to investigate, develop and document the facts of the case, to research the applicable legal principles, to analyze the legal issues of the matter, to present and communicate legal positions, and to develop strategies to solve the problems. The difficulty and complexity of the cases increase each semester. In the Master's program, cases often require both legal and economic judgment and counselling. 124 From the outset students are required to work in teams and to organize their work process, thus providing a collaborative experience often encountered in the actual practice of law.

\footnotetext{
123 See the examination regulation for the Bachelor's program "Wirtschaftsrecht" http://www.wi.hswismar.de/fbw/studium/wr/ordnungen/bachelor-po.pdf (last accessed March 9, 2008). The clinical courses are called "Fallstudien". See also the examination regulation for the Master's program "Wirtschaftsrecht http://www.wi.hs-wismar.de/fbw/studium/wr/ordnungen/master-po.pdf: in the Master's program the clinical courses are called "Interdisziplinäre Fallstudien" (Interdisciplinary Case Studies) because they cover to a higher degree than the Bachelor's "Fallstudien" legal and economic issues at the same time.

124See Bücker, Andreas / Gabriel, U1rich, Gründung einer Internet-Apotleke - Eine wirtschaftsrechtliche Fallstudie, 47 JURISTISCHE SCHULUNG (JUS) 2007, 60-64.
} 
This simulated exercise in the practice of law changes the role of the traditional German law professor into that of a coach, mentor, and supervisor. They monitor the working processes of the students and assist by providing guidance and direction as the problem develops and the students progress. To add realism to the exercise, they play different roles like clients, investors or public authorities which supply - on request of the students - additional information or decisions needed to resolve the problem at hand. We often use teams of professors and practitioners to provide the oversight and direction necessary to develop the teaching points of a given problem.

The results of this way of teaching have been so encouraging that the Hochschule Wismar last year started a small live client clinical program for Master students and dedicated one professorship to this task. Students in the live client clinic work under the supervision of their professor and licensed practitioner to handle real problems of real clients instead of resolving problems of a simulated client. The live client clinic adds the human reality component to the development of professional skills and values that a simulation cannot duplicate.

The concept of live client clinics is only feasible, however, if it is consistent with the Rechtsberatungsgesetz (statute regulating the practice of law). According to Art. $1 \S 1$ Abs. 1 S. 1 Rechtsberatungsgesetz the handling or management of legal issues for others is reserved to those who have been admitted to practice law. Since law clinics are designed to give students - who are not yet lawyers - opportunity to represent real clients the Rechtsberatungsgesetz could pose some difficulties.

Some exception to Rechtsberatungsgesetz may grant clinical programs some room to operate: Art. $1 \S 3 \mathrm{Nr}$. 1 Rechtsberatungsgesetz allows corporate bodies of public law to provide legal advice within the scope of its competence. Almost all student unions in Germany offer legal advice for the students of their university although there are strict limitations. ${ }^{125}$ Within the limitations of Art. $1 \quad \S \quad 3 \mathrm{Nr} .1$ Rechtsberatungsgesetz giving legal aid to students can be one field of activity for clinics in Germany. In the field of business law there might also be an area of application for Art. $1 \S 2$ Rechtsberatungsgesetz which states that scientific expert opinions can be given by one without the law license required by Art. $1 \S 1$ Abs. 1 S. 1 Rechtsberatungsgesetz.

Because live client clinics involve real people with real legal problems, the students must work under the supervision and guidance of a licensed lawyer. The lawyer can be a professor who holds a legal permission or a lawyer who is an adjunct

${ }^{125}$ See OLG Stuttgart, Beschl. vom 20.01.1989, Az. 4 Ss 481/88, NStE Nr 2 zu Art 1 \$ 7 RBerG. 
professor. This is similar to the practice in the US and will avoid conflicts with the Rechtsberatungsgesetz. Care must be taken to avoid giving the students too much freedom so that they effectively practice law without a license to the prejudice of the client. On the other hand, to derive the maximum educational benefit for the students, the supervision must be such that the students experience legal practice instead of just watching their professor or supervisor practice law. Importantly, the clinical experience should include an opportunity for the students to reflect upon their participation and to assess their own development of the professional skills and values the course is trying to inculcate.

A repeal and replacement of the Rechtsberatungsgesetz scheduled to become effective 30 June 2008 will minimize the possibility of the unlawful practice of law in live client clinics. The new Rechtsdienstleistungsgeset $z^{126}$ allows gratuitous legal counselling by law students under the supervision of someone who is qualified by successful passage of the Erste and Zweites Staatsexamen. This will create a situation similar to that found in most US student practice rules. We urge German law faculties to take full advantage of this new flexibility and opportunity to train their students.

\section{Allocating Resources}

In comparison to other study programs, juridical study programs are inexpensive. The Referendariat, however, is not. Students in this two-year practical training program receive a salary. While they assist the particular office or agency in conducting business they are not lawyers and cannot practice law. Thus, their contribution to the overall work product of the office or agency is limited, yet they are on the payroll. Some have suggested the costs of the Referendariat could, in the long run, be the reason for its disestablishment. ${ }^{127}$ If the Referendariat is reduced or eliminated, to accommodate the Bologna Process, the legal skills and competences previously developed during the Referendariat must be taught as part of the law curriculum of German universities.

The development of practical legal skills is - as the American experience shows much more expensive than traditional academic teaching. If the Referendariat is eliminated or limited to a smaller group of young lawyers who will become judges

\footnotetext{
126 Gesetz über aufergerichtliche Rechtsdienstleistungen vom 12.12.2007, BGB1 I 2007, 2840.

127 Ulrich Goll, Bachelor und Master statt Staatsexamen und Referendariat, 62 BETRIEBS BERATER (BB) Die erste Seite, Heft 20 (2007); Hartmut Kilger, Wie der angehende Anwalt ausgebildet sein muss, 57 ANWALTSBLATT (ANWBL) 1 - 5 (2007), Joachim Jahn, BB-Forum: 56. Deutscler Anwaltstag - Advokaten unter Druck, 60 BB, 1180, (2005). Barbara Dauner-Lieb, Der Bologna-Prozess - endgültig kein Thema für die Juristenausbildung? 56 ANWBL 5 - 9 (2006).
} 
or civil servants, universities should seek to acquire some of that funding previously devoted to the Referendariat and use it to implement clinical programs in their own curriculum. Redirecting the public funds used to pay students in the Referendariat to university clinical programs will facilitate the development skills training in law school and compensate for the loss or reduction of the Referendariat.

\section{Curricular Development}

Much of the debate surrounding the Bologna Process and German legal education is about whether the traditional program leading to the Erste Staatsexamen should be changed to a "two cycle system" leading to two degrees, the Bachelor's and the Master's degree, which might lengthen the course of study. ${ }^{128}$ The debate, however, should not be confined to these structural issues. Rather, it should include the important topic of curricular development. One of the major aims of the Bologna Process is to modernize higher education systems in order to provide graduates with competences and skills required for a successful career and active participation in the economy and society. Universities must prepare their graduates for the challenges of changing societies and become more flexible and more responsive to the needs of society. In this context, a shift from providing merely technical legal knowledge to integrating professional skills and values is required. ${ }^{129}$

This issue is directly linked to the crucial question of the overall concept of legal education: the two endpoints of the spectrum are a purely academic education on the one hand and a purely practical education on the other hand. In other words: shall students learn to think like lawyers or shall they learn to act like lawyers. As already mentioned, for the American situation it is plausible for mainstream legal education to have a foot in both camps. Although this is plausible most of the traditional programs leading to the Erste Staatsexamen have their focus much more on legal analysis than on professional skills and competences.

Changing to the Bachelor's and Master's structure frees us from the necessity to define one unique and binding position on the spectrum. Within the Bachelor's and Master's structures universities can develop their individual answers, profiles, and programs. If universities in Germany really take up this issue we should not

\footnotetext{
128 Heino Schöbel, Die Bologna-Erklärung und die Juristenausbildung - Ein Bericht, 138 BAYERISCHE VerWAltungsblätter (BAYVBL) 97 (2007); Günter Krings, Der Bologna-Prozess und seine Auswirkungen auf die Juristenausbildung in Deutschland, 42 RECHT UND POLITIK 18 (2006), Barbara Dauner-Lieb, Der Bologna-Prozess - endgültig kein Thema für die Juristenausbildung? 56 ANWBL 5 (2006).

129 See supra note 4.
} 
exaggerate the expectations: as the MacCrate Report pointed out law schools can not fully inculcate all professional skills and competences into every graduate ${ }^{130}$. The development of legal skills and values is a lifelong endeavour.

\section{What are the Necessary Legal Competences?}

If universities take up this challenge and commit to developing professional skills and values they must decide which skills and values are essential. In this respect, the American example is also helpful. The essential skills and values the MacCrate Report identified are fundamental for the education of German lawyers, as well. Potential accommodations, changes, or modifications of the current curriculum should, of course, be debated in a broad and public discussion. For instance, the first essential skill identified by the MacCrate Report is Problem Solving. ${ }^{131}$ Mainstream German legal education today focuses more on the legal analysis of problems than on developing and implementing solutions and strategies to address and solve the problem. Taking this skill seriously would have substantial influence on the current German curriculum. Other skills like factual investigation, communication, and negotiation are certainly relevant legal competencies. If universities integrate these competencies into their curricula, they will have to complement their traditional ways of academic teaching with new methods like clinical education. This, of course, has substantial consequences on the faculty and the allocation of financial resources. Perhaps further competencies should be considered and supplemented in addition to those competencies mentioned in the MacCrate Report. In view of internationalization, foreign language skills and intercultural competences should be considered. This brief article is not designed to answer all of these questions, but to begin the discussion.

\section{Internationalization}

The Bologna Process addresses internationalization, inter alia, by strengthening student mobility and promoting the European dimension in higher education. ${ }^{132}$ Clinical education supports these goals better than the traditional practice.

Although the Referendariat makes it possible for students to spend some period abroad, there are shortcomings. The German system does not offer many possibilities for foreign students to take part in practical education in Germany and

\footnotetext{
130 See supra note 45.

131 See supra note 58 .

132 See The Bologna Declaration 19 June 1999, http://www.bologna-berlin2003.de/pdf/bologna _declaration.pdf (last accessed March 9, 2008).
} 
it offers virtually no opportunities for German and foreign students to gather experiences in concerted activities where German and foreign students work together. Clinical education in the law school curriculum, on the other hand, offers many opportunities to experience legal practice abroad both for German and foreign students. As we have pointed out, virtually all American universities offer clinical law programs. Clinical programs are also becoming an integral part of legal education in Australia, Canada, Latin America and Africa. It is also emerging in the United Kingdom. In Central and East Europe including Russia we see a very strong development of clinical education. ${ }^{133}$ The recent development in Central and East Europe shows that the concept of clinical legal education matches well the objectives of the European higher education reforms. In the mid 1990s clinical legal education started on an experimental level in Central and Eastern Europe. This was a period of fast development and change in society as well as in education. Since then a broad variety of Bachelor and Master programs in Law have been established. ${ }^{134}$ The classical way to let students experience legal practice - the "Praktikum" - was considered insufficient because the pedagogic content and the teaching component are suboptimal. ${ }^{135}$ The German "Referendariat" was not an attractive alternative because it is too expensive and its duration is too long. However, the success of the clinical approach in Central and East Europe is quite impressive. Today we observe a constantly growing number of clinical programs in this region and a variety of networks are developing as well. ${ }^{136}$ The reasons for this success are manifold: clinical education can be easily adapted to different jurisdictions and the concept is well in line with the goals of the Bologna Process and the strategy of the European Commission. ${ }^{137}$ Clinical legal education facilitates partnerships and communication between academia and society, it focuses on skills

\footnotetext{
133 See http://www.pili.org/en/component/option,com_frontpage/Itemid,1/ (last accessed March 9, 2008).

134 See, e.g., http://1lm.uniiks.com/search/continent/Europe/countries (last accessed March 9, 2008).

135 Edwin Rekosh, The Possiblities For Legal Education in Central and Eastern Europe, http:/ / www.pili.org/en/content/view/158/26/ (last accessed March 9, 2008).

136 See, e.g., http:/ / www.abanet.org/rol/programs/legal-education.html (last accessed March 9, 2008); Legal Clinics in Poland: http://www.fupp.org.pl/index_eng.php (last accessed March 9, 2008), with a helpful linklist; Public Interest Law Initiative: http://www.pili.org/en/content/view/495/210/ (last accessed March 9, 2008), Global Alliance for Justice Education: http://www.gaje.org (last accessed March 9, 2008).

137 Communication from the Commission to the Council and the European Parliament: Delivering on the Modernisation Agenda for Universities, $\mathrm{KOM}(2006) 208$ final, pages 6-10, http://eurlex.europa.eu/LexUriServ/site/en/com/2006/com2006_0208en01.pdf (last accessed March 9, 2008).
} 
and competencies for the labor market, enhances interdisciplinary study, and thus makes higher education in Europe more effective, efficient, and attractive. ${ }^{138}$

A further aim of the Bologna Process is to promote the European dimension in higher education particularly with regards to programs of study, training and research. ${ }^{139}$ Incorporating clinical education into German legal education will strengthen the international goals of the Bologna Process by facilitating Germany's integration into existing international networks of clinical legal education. Making clinical education a part of the German legal academy will also strengthen the European dimension of the curriculum. The present Referendariat focuses specifically on German-specific know-how of a technical nature. Clinical legal education, on the other hand, develops skills, competencies, and values that transcend national borders and further promote the transnational goals of the Bologna Process. At the same time, the flexibility of the clinical model allows emphasis, depending upon the specific subject matter of a given clinic, on countryspecific law, like the current Referendariat, or concepts of international law or transactions. In either situation, the Bologna Process goals are furthered.

\section{Conclusion}

The Bologna Process goal of standardizing European higher education presents unique challenges for German legal education. The current university training leading to the Erste Staatsexamen, followed by the two-year Referendariat and the Zweite Staatsexamen hinders the internationalization of the curriculum and makes compliance with the Bologna mandates extremely problematic. We think German legal educators should consider how the incorporation of clinical programs may assist in bringing legal education into compliance with the Bologna Process and, at the same time, begin to develop in law students the skills, competencies, and values needed for a successful legal career. We look forward to the debate and discussions that will follow on this vital topic.

\footnotetext{
138 See also Lusine Hovhannisian, Clinical Legal Education and the Bologna Process, PILI Papers, Number 2, December 2006, http://www.pili.org/en/dmdocuments/pili_papers_2_3.pdf (last accessed March 9, 2008).

${ }_{139}$ Joint declaration of the European Ministers of Education convened in Bologna on the 19th of June 1999, http:/ / www.bologna-berlin2003.de/pdf/bologna_declaration.pdf (last accessed March 9, 2008 ).
} 